\title{
The Business and Accounting Technology Innovation for Better Firm Performance: A Case of Malaysian Firms
}

\author{
Maher A. Al-Shmam \\ University of Mosul, Iraq \\ Hosam Alden Riyadh \\ Universitas Muhammadiyah Yogyakarta, Jl. Brawijaya, \\ Geblagan, Tamantirto, Kec. Kasihan, Bantul, \\ Daerah Istimewa Yogyakarta 55183, Indonesia \\ Salsabila Aisyah Alfaiza \\ University of Airlangga, Jl. Airlangga No.4 - 6, \\ Airlangga, Kec. Gubeng, Kota SBY, Jawa Timur 6o115, Indonesia
}

DOI: https://doi.org/10.36941/ajis-2021-0153

\section{Abstract}

Business and Accounting Technology innovation can play a significant role in enhancing economic growth and has the potential to bring about change and create opportunities for every business Within the introduction of a wide variety of new technologies during the fourth industrial revolution, therefore, this study aimed to evaluate the impact of business innovation, technology orientation and Accounting technological innovation capabilities on firm performance in the Malaysian firms. To achieve this objective 337 sample responses were collected from the business managers of Malaysian firms related to technology and innovation using the purposive sampling technique. Furthermore, this study has used explanatory purpose because of the reason that it gives effective and enhanced understanding PLS-SEM was employed for data analysis using Smart-PLS version 3.2.8. The results have shown that business innovation and technology orientation have a significantly positive effect on technology innovation capability while accounting technology innovation capability has a positive significant effect on firm performance. Implications are the Managers needs to be more aware regarding OI and TICs and how these two processes simultaneously can affect the firm performance. In addition, managers can easily use OI to develop their skills, methods, and innovation aspects. The managers are recommended to provide employees a creative environment and motivate employees to work in an open environment so that it can increase the accounting technological innovation capabilities.

Keywords: Business Innovation, Technology Orientation, Technology Innovation, Malaysia, PLS-SEM

\section{Introduction}

The aspect of organizational innovation has been termed as a necessary element as it helps in developing firm performance and creates innovative methods and resources in practices of firm's 
business, workplaces and increases innovation activities and their outcomes as well (Camisón \& Villar-López, 2014). Also, this innovation refers to identify capabilities that could create new ideas with help of innovative practices and technologies (Seyfang \& Smith, 2007). There has been a general perspective that OI helps in enhancing the performance and there have been various studies that examined the factors of OI, process, and products (Ballot, Fakhfakh, Galia, \& Salter, 2015; Camisón \& Villar-López, 2014; Carboni \& Russu, 2018; Lee, Lee, \& Garrett, 2019) but there are very few studies that studied relationships regarding OI and technological innovation capabilities (TIC) which helps in gaining high performance. Similarly, prior research has studied product and process innovation regarding the perspective of TIC; the variables were examined with isolation and when included as a group it did not provide any clear theoretical aspect.

There have been researches that have included OI as an important factor of TIC and towards the performances and showed empirically that OI is significant towards technological innovation (Battisti \& Stoneman, 2010; Camisón \& Villar-López, 2014). In addition, there have been different kinds of literature that show complementary views that in what process OI of a firm develops TIC which leads towards an increase in firm performance. For instance, (Damanpour, Szabat, \& Evan, 1989; Sapprasert \& Clausen, 2012) stated that organizations that have high OI would also develop their TIC and is crucial to firm performance. However, till now there is no great research in explaining the aspect of TICs that could help in identifying the relationships between previous factors and high performance.

However, there have been grave concerns during the last decade that consumption of products and advancements in technological aspects were the reasons for the rise in ecological and social problems globally. In addition, the term technological orientation (TO) can be viewed as the capability of a firm to view and adapt to the new technologies (Bamgbade, Nawi, Kamaruddeen, Adeleke, \& Salimon, 2019; Gatignon \& Xuereb, 1997). Also, technology orientation identifies the firm's view and their ability that could help in gaining a substantial position and create new products by using technological improvements. So, this helps in understanding that such firms that have TO uses modern technologies for their product delivery and in the aspect of R\&D as well (Akcigit \& Kerr, 2018; Ali, Leifu, \& Rehman, 2016). Additionally, different studies have stated that the aspect of TO-can help in revolutionizing the products of a firm and increase their performance at a significant level (Wong \& Zhou, 2015).

To the best of the researcher's knowledge, there has not been a study that examined this and it requires attention in identifying the role of $\mathrm{OI}$ and $\mathrm{TO}$ that affects technological innovation capabilities and can further affect the firm performance. Hence, this study has aimed to study these relationships and effectively describe and identify their role.

In addition, this study will provide results that can be beneficial for both practitioners and academicians. At first, as the study has described each variable briefly the academicians can use those and understand more properly by their results and findings of OI and TICs. Also, practitioners can use these results for properly identifying the use of OI and TICs and that it is better to adopt this aspect together for effective use. The practitioners can use this study for developing their firm performance by implementing and increasing organizational innovation and TICs.

The study aimed to evaluate the impact of business innovation, technology orientation, and Accounting technological innovation capabilities on firm performance in Malaysian firms. The remaining study has been conducted in the second chapter includes theoretical background, hypothesis development, and conceptual framework. The third chapter includes research methodology and design for collecting data and their analysis. The fourth chapter includes data analysis and its interpretations and discussions. The fifth chapter includes the conclusion, managerial recommendations, and future research recommendations

\section{Literature Review}

The scholars have highly stated that if firms want to gain a competitive advantage it is necessary to adapt organizational or business innovation (Camisón \& Villar-López, 2014; Tuan, Nhan, Giang, \& 
Ngoc, 2016). The implementation of innovation in firms refers to applying new skills, approaches, and collaborative relations. The aspect of OI has a deep and wide meaning that could help an organization to facilitate and gain innovative outputs by deviating from old to new technologies (Chen, Wang, \& Huang, 2020). Although, the definition of OI has been referred to as such products and services that were new for the organization when it was being adopted. Also, it can be identified as new methods of a firm that are implemented in the workplace, practices, and external activities (Guimaraes \& Paranjape, 2017; Kahn, 2018). So, this aspect defines that an increase in innovative efforts of a firm would increase innovative outcomes as well. The process of OI is related to nontechnological innovation (Ballot et al., 2015). However, different researchers have stated that OI has relations with other innovative efforts that include service innovation, products, and processes (Camisón \& Villar-López, 2014).

The aspect of technological innovation capabilities helps the organization to respond to changes in the market and adapt innovation and technologies (Ince, Imamoglu, \& Turkcan, 2016). However, there has not been an accepted definition of TICs but in the traditional perspective of innovation, it could be identified as a process that adapts complete technological innovation aspect. There have been different studies that defined single concepts of TICs but never had any success (Chen et al., 2020). For instance, Shafia, Shavvalpour, Hosseini, and Hosseini (2016) TICs is a mixed concept that can refer to the innovation activities of a firm. So, the simple definition is that TICs are an innovation that comes from different dimensions and is an interaction function. Also, it is a complex aspect that develops, gain and integrate diverse skills and knowledge that are necessary for innovating complex technologies (Wang, Lu, \& Chen, 2008).

The theory of OI refers to that such firms that use external and new knowledge that could be determined in the exploitation of technology and its application (Gemünden, Lehner, \& Kock, 2018). The role of organizational innovation can develop TICs and the reason is that it adopts different and new methods and skills which can eventually help fulfill the needs of innovation (Azar \& Ciabuschi, 2017; Camisón \& Villar-López, 2014). As previous studies have showed that OI has a positive effect towards TICs (Anzola-Román, Bayona-Sáez, \& García-Marco, 2018). Also, such a firm that has an innovation-oriented concept requires OI and its capabilities to develop their TICs and especially in an ever-increasing and competitive market. Similarly, different research has shown that the role of OI helps develop their TICs that could help in creating an innovative environment for technological innovation (Carboni \& Russu, 2018; Damanpour et al., 1989)

The basic concept of technology orientation is that through this a firm identifies and adapts new and innovative technologies. More specifically, TO in R\&D refers to achieving a comprehensive level of improvements in technology that could develop new products (Bamgbade et al., 2019; Gatignon \& Xuereb, 1997). So, this concept means that firms increase their innovation capabilities by using technology orientation because it helps in increasing product delivery. In addition, prior researchers have identified that firms must gain innovative capabilities so that they could help in developing strategic capabilities (Jantunen, Ellonen, \& Johansson, 2012). Similarly, the adoption of technology orientation helps in developing the firm's TICs because it refers to using new ideas, skills, business methods, and services (Hortinha, Lages, \& Lages, 2011; Khan \& Naeem, 2018).

The implementation of accounting technological innovation is highly dependent on OI and both are equally important to the innovative activities of a firm (Anzola-Román et al., 2018). Also, prior studies have mentioned that such firms that are moving towards technological innovation must-have skills, procedures, and capability as well (Azar \& Ciabuschi, 2017; Chandy, Prabhu, \& Antia, 2003). Therefore, the firms adopt TICs that could help in creating effective innovative capabilities and implement successful innovations (Kogan, Papanikolaou, Seru, \& Stoffman, 2017). So, to know about mixing up organizational and technological capabilities and their benefits Chen et al. (2020) stated that to gain effective innovation processes the firms are required to align with strategic implementation. This is the reason that TICs are required to successfully have a good innovation strategy that could effectively increase their competitive advantage (Burgelman, Maidique, \& Wheelwright, 1996). Similarly, the reason for using TICs is that it develops higher innovation that 
leads towards increased firm performance (Hailekiros \& Renyong, 2016; Rahim \& Zainuddin, 2019; Yam, Lo, Tang, \& Lau, 2011). The TICs of a firm can be viewed as a total perspective regarding innovation and then it jointly increases the firm performance as well (bin Zainuddin, 2017; Guan, Yam, Mok, \& Ma, 2006).

\section{Hypotheses Development}

Based on the above discussion, the hypotheses for these variables are presented in the following hypotheses statements.

H1: Organizational innovation has a significant effect on accounting technological innovation Capabilities.

H2: Technology orientation has a significant effect on accounting technological innovation capabilities

$\mathrm{H}_{3}$ : Technological innovation capabilities have a significant effect on firm performance.

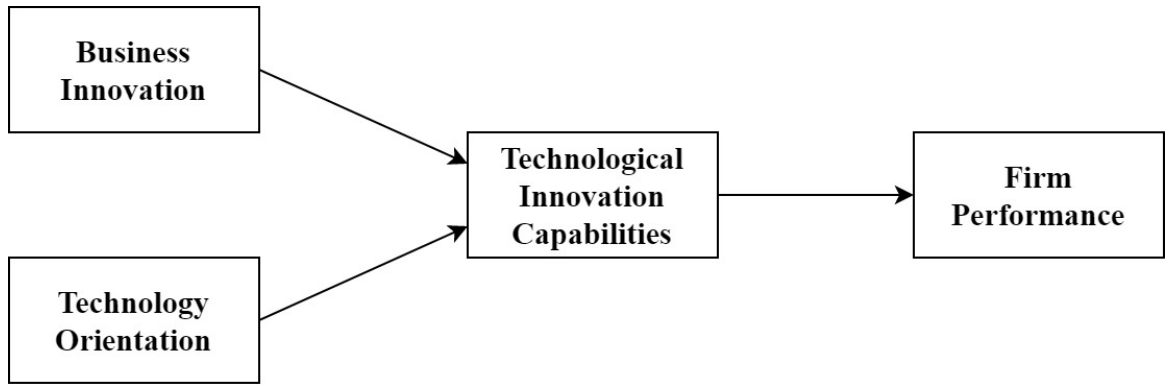

Figure 1: Research Framework

\section{Research Methods}

There are different research approaches named quantitative, qualitative, and mixed. The quantitative approach is a very simple and general approach that is based on numeric or statistics. This approach is based on theory testing and hypothesis development (Lynham, 2002). Also, it is relatively easier to conduct and collect data through this approach. This approach helps the researcher in gathering the data with high representativeness and in less amount of time with low cost as well (Welman, Kruger, \& Mitchell, 2005). Hence, this study has used a quantitative approach for data collection as it helps in collecting a large amount of data and provides more generalized results as well.

There are two types of research purpose known as explanatory and exploratory purpose. The explanatory purpose refers to examine the research objective in a more detailed and enhanced manner (Scandura \& Williams, 2000). Similarly, it provides in-depth knowledge or information for the researcher to better understand the research and its variables. This purpose is very useful in quantitative research as it gives proper findings in a statistical manner (Saunders, Lewis, \& Thornhill, 2009). Therefore, this study has used explanatory purpose because of the reason that it gives effective and enhanced understanding.

The research design refers to identifying the relationships between variables. There are two types of designs named experimental and non-experimental. The causal design can be defined as identifying the relationships between variables based on cause and effect (Creswell, 2002). This design simply examines their causes and effects, and it also identifies the strength and direction of their relationships (Sekaran \& Bougie, 2010). Hence, this study has used causal design for identifying the relationships and the reason is that it provides causal and effect relations.

There are two major types of sampling techniques named probability and non-probability. The 
purposive sampling technique is a non-probability sampling and it means that the researcher selects participants based on their judgment (Sekaran \& Bougie, 2016). Also, this technique means that the participants have some specific and particular information or knowledge regarding the research objective. This technique provides more in-depth and relatable data regarding research variables (Etikan, Musa, \& Alkassim, 2016). Therefore, this study has used purposive sampling because it can give more specific data.

The PLS-SEM analysis technique is very effective and can be used to examine the small sample size data as well. The most important aspect of this technique is that it provides consistency and reliability of the data using Cronbach's alpha (J F Hair, Christian M Ringle, \& Marko Sarstedt, 2011). Also, this technique helps get hypothesis testing and it provides predictive relevance as well (Hair, Sarstedt, Ringle, \& Mena, 2012). Hence, this study has used PLS-SEM using SmartPLS 3.2.8 because of its ability to give in-depth results and relatively more valid findings.

\section{Data Analysis}

Table 1: Demographic profile of total 337 respondents.

Following table 1 shows the demographic profile of total 337 respondents.

\begin{tabular}{|c|c|c|c|}
\hline & & Frequency & Percent \\
\hline \multirow{3}{*}{ Gender } & Male & 199 & 59.1 \\
\hline & Female & 138 & 40.9 \\
\hline & Less than 20 years & 36 & 10.7 \\
\hline \multirow[t]{3}{*}{ Age Groups } & 21-30 years & 277 & 82.2 \\
\hline & $31-40$ years & 24 & $7 \cdot 1$ \\
\hline & Undergraduate & 90 & 26.7 \\
\hline \multirow[t]{3}{*}{ Education } & Graduate & 174 & 51.6 \\
\hline & Post-Graduate & 73 & 21.7 \\
\hline & Less than 250 employees & 84 & 24.9 \\
\hline \multirow{3}{*}{ Firm Size } & 250 to 500 employees & 85 & 25.2 \\
\hline & 500 to 1000 employees & 90 & 26.7 \\
\hline & More than 1000 employees & 78 & 23.1 \\
\hline
\end{tabular}

The following table shows the measurement model statistics for construct and convergent validity using PLS-SEM estimations.

Table 2: Measurement Model

\begin{tabular}{|c|c|c|c|c|}
\hline Construct & Items & Loadings & CR & AVE \\
\hline \multirow{4}{*}{ Business Innovation } & BI1 & 0.771 & \multirow{4}{*}{0.858} & \multirow{5}{*}{0.603} \\
\hline & $\mathrm{BI}_{2}$ & 0.856 & & \\
\hline & $\mathrm{BI}_{3}$ & $0.75^{8}$ & & \\
\hline & $\mathrm{BI}_{4}$ & 0.713 & & \\
\hline \multirow{3}{*}{ Firm Performance } & FP1 & 0.872 & \multirow{3}{*}{0.911} & \\
\hline & $\mathrm{FP}_{3}$ & 0.896 & & \multirow[t]{2}{*}{0.773} \\
\hline & $\mathrm{FP}_{4}$ & 0.870 & & \\
\hline \multirow{2}{*}{ Accounting Technology Innovation Capability } & $\mathrm{TIC}_{1}$ & 0.908 & \multirow{2}{*}{0.886} & \multirow{2}{*}{0.796} \\
\hline & $\mathrm{TIC}_{3}$ & 0.875 & & \\
\hline \multirow{2}{*}{ Technology Orientation } & $\mathrm{TO}_{2}$ & 0.614 & \multirow{2}{*}{0.777} & \multirow{2}{*}{0.646} \\
\hline & $\mathrm{TO}_{4}$ & 0.957 & & \\
\hline
\end{tabular}

The above table has a recommended threshold that for the absolute retention the values should be 
greater than 0.70 . However, the values less than 0.40 should be deleted and the values between 0.40 and 0.70 can be accepted based on convergent validity (J F Hair, Christian M. Ringle, \& Marko Sarstedt, 2011). The above table has all values within the recommendations. In addition, the recommended threshold for composite reliability is that values should be greater than 0.70 and for AVE is greater than 0.50 (Hair, Ringle, \& Sarstedt, 2013). Hence, the above has all values greater than the threshold and has achieved a measurement model.

Table 3: Fornell and Larcker (1981) Criterion

\begin{tabular}{lcccc} 
& BI & FP & TIC & TO \\
\hline Business Innovation & $\mathbf{0 . 7 7 6}$ & & & \\
Firm Performance & 0.335 & $\mathbf{0 . 8 7 9}$ & & \\
Technology Innovation Capability & 0.317 & 0.701 & $\mathbf{0 . 8 9 2}$ & \\
Technology Orientation & -0.072 & 0.264 & 0.312 & $\mathbf{0 . 8 0 4}$ \\
\hline
\end{tabular}

The above table has a recommended threshold that all diagonal and bold values should be greater than compared to the values in other constructs (Fornell \& Larcker, 1981). Hence, this study has accomplished discriminant validity using Fornell and Larcker (1981) criterion.

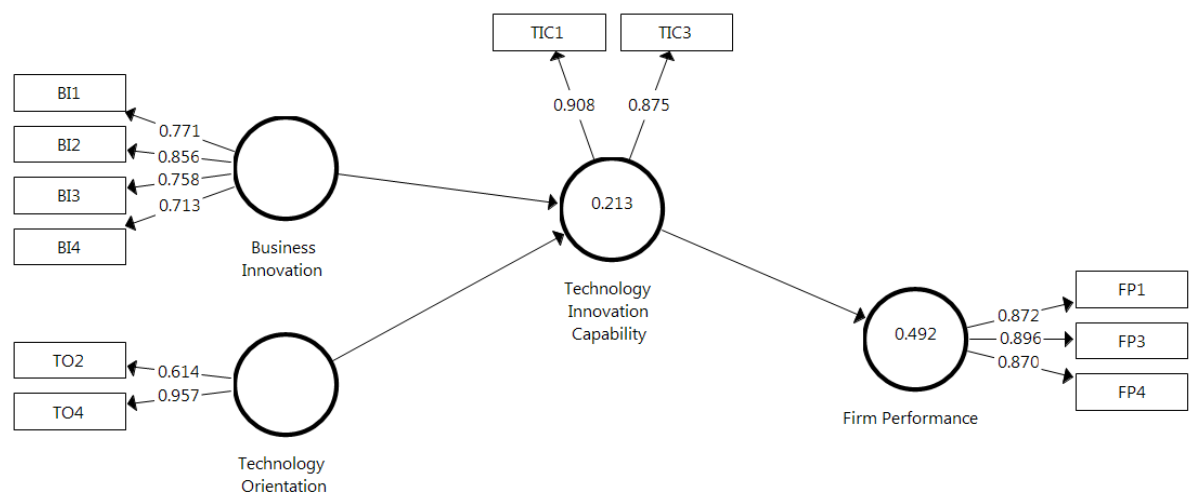

Figure 2: PLS Algorithm

Table 4: Crossloadings

\begin{tabular}{ccccc} 
& BI & FP & TIC & TO \\
\hline BI1 & $\mathbf{0 . 7 7 1}$ & 0.126 & 0.271 & -0.004 \\
$\mathrm{BI}_{2}$ & $\mathbf{0 . 8 5 6}$ & 0.344 & 0.316 & -0.092 \\
$\mathrm{BI}_{3}$ & $\mathbf{0 . 7 5 8}$ & 0.211 & 0.116 & -0.128 \\
$\mathrm{BI}_{4}$ & $\mathbf{0 . 7 1 3}$ & 0.360 & 0.190 & -0.029 \\
$\mathrm{FP} 1$ & 0.318 & $\mathbf{0 . 8 7 2}$ & 0.583 & 0.194 \\
$\mathrm{FP}_{3}$ & 0.243 & $\mathbf{0 . 8 9 6}$ & 0.584 & 0.211 \\
$\mathrm{FP}_{4}$ & 0.318 & $\mathbf{0 . 8 7 0}$ & 0.673 & 0.283 \\
$\mathrm{TIC}_{1}$ & 0.223 & 0.702 & $\mathbf{0 . 9 0 8}$ & 0.308 \\
$\mathrm{TIC}_{3}$ & 0.353 & 0.539 & $\mathbf{0 . 8 7 5}$ & 0.245 \\
$\mathrm{TO}_{2}$ & -0.018 & 0.065 & 0.120 & $\mathbf{0 . 6 1 4}$ \\
$\mathrm{TO}_{4}$ & -0.079 & 0.288 & 0.325 & $\mathbf{0 . 9 5 7}$ \\
\hline
\end{tabular}

The above table has a recommendation that each horizontal construct should have a higher value in its construct for acceptance (Hair et al., 2013). So, this table has values according to the 
recommendations and thus discriminant validity has been achieved using cross-loadings.

Table 5: HTMT Ratio

\begin{tabular}{|c|c|c|c|c|}
\hline & BI & FP & TIC & Tо \\
\hline \multicolumn{5}{|l|}{ Business Innovation } \\
\hline Firm Performance & 0.411 & & & \\
\hline Technology Innovation Capability & 0.377 & 0.867 & & \\
\hline Technology Orientation & 0.217 & 0.353 & 0.432 & \\
\hline
\end{tabular}

The above table has a threshold that to be acceptable the values must be less than o.9o (Henseler \& Fassott, 2010). The table has shown all values higher than the threshold and therefore discriminant validity has been achieved using HTMT ratio.

\section{Table 6: Path Analysis using PLS-SEM}

\begin{tabular}{ccccc} 
& Estimate & S.D. & T-Stats & Prob. \\
\hline Business Innovation -> Tech. Innovation Capability & 0.341 & 0.039 & 8.810 & 0.000 \\
Tech. Innovation Capability -> Firm Performance & 0.701 & 0.030 & 23.268 & 0.000 \\
Tech. Orientation -> Tech. Innovation Capability & 0.337 & 0.039 & 8.657 & 0.000 \\
\hline
\end{tabular}

The results have shown that business innovation (0.341, p < 0.001) and technology orientation ( 0.337 , $\mathrm{p}<\mathrm{o.001}$ ) have significantly positive effect on technology innovation capability while technology innovation capability $(0.701, \mathrm{p}<0.001)$ has positively significant effect on firm performance.

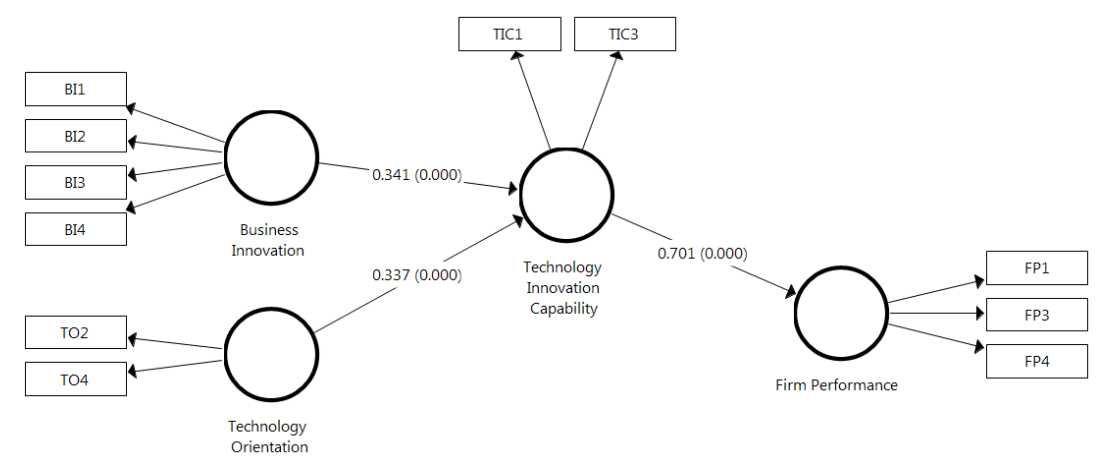

Figure 3: PLS Bootstrapping

\section{Result and Discussion}

This study aimed to evaluate the effects of business innovation, accounting technology orientation, and technological innovation on firm performance. The part played by the business innovation and accounting technology orientation to facilitate and stimulate technologically innovative capabilities was also evaluated (Camisón \& Villar-López, 2014). The outcomes indicated that business innovation facilitates in developing the TICs that also results in improving firm performance. Moreover, the outcomes showed that accounting technology orientation also increases technological innovation capabilities. It was also found that the TIC also moderates the relationship between business innovation and firm performance (Evangelista \& Vezzani, 2010).

The findings showed that the enhanced impact of TIC on the performance of the firm increases 
the firm strength with the help of developed business innovation. Also, the accounting technology innovation capabilities are among the significant factor for innovation in markets that are arising and is focused on many studies in different forms (Camisón \& Villar-López, 2014). The research sought to increase the past studies on innovation and its impact on the firm performance. Furthermore, the role of technological orientation can also not be neglected as it impacts the technological innovation capabilities which also highlights how it is another factor that plays a key role to enhance the firm performance (Evangelista \& Vezzani, 2010). steady with past thinks about has appeared that OI encompasses a positive impact on TICs (Anzola-Román, Bayona-Sáez, \& García-Marco, 2018). Moreover, such a firm that has an innovation-oriented concept requires OI and its capabilities to create their TICs and particularly in an ever-increasing and competitive advertising. Essentially, distinctive inquire about has appeared that the part of OI makes a difference create their TICs that seem to offer assistance in making an imaginative environment for mechanical development (Carboni \& Russu, 2018; Damanpour et al., 1989). that steady with the hypothesis of OI alludes to that such firms that use outside and new information that may well be decided within the misuse of innovation and its application (Gemünden, Lehner, \& Kock, 2018). The part of organizational advancement can develop TICs and the reason is that it embraces diverse and unused strategies and aptitudes which can inevitably offer assistance fulfill desires of advancement (Azar \& Ciabuschi, 2017; Camisón \& Villar-López, 2014).

\section{Conclusion}

The current paper has effectively examined the aspect of technological innovation capabilities and firm performance. This study has used a quantitative approach for data collection. The results have provided an in-depth understanding towards OI and TICs and how it contributes towards firm performance. Based on OI theory, this paper highlighted the role of OI that it plays in developing the aspect of TICs and it eventually affects firm performance. So, this study has contributed to the literature by identifying the relationships between OI and TICs and TICs and performance.

The current study has given beneficial results and this section gives necessary recommendations to managers. At first, managers need to be more aware of OI and TICs and how these two processes simultaneously can affect firm performance. In addition, managers can easily use OI to develop their skills, methods, and innovation aspects. The managers are recommended to provide employees a creative environment and motivate employees to work in an open environment so that it can increase the accounting technological innovation capabilities. Also, it is recommended to use proper elements or tools and encourage diversity so that every employee can perform at their best and achieve high innovative capability.

Moreover, the manager should realize that both OI and TICs are not different activities and they should be combined to increase the innovation process. Also, managers are recommended to increase their superior performance of the firm by implementing a combined aspect of OI and TIC in their firms. The managers are also recommended to increase their technology orientation that could help in increasing TICs. This process can be improved by using and adopting new technologies for creating innovation in the development of products and their delivery.

This research has faced some limitations and it has some future recommendations. At first, this study has collected data of firms in Malaysia and thus the results cannot be generalized to other countries. Second, this study did not study the mediation effects of OI and TO and future researches are recommended to study these relationships as well. A third, this study has used a quantitative approach for collecting data and thus could be limited so, future researches are recommended to adopt a qualitative manner for in-depth results. A fourth, the knowledge sharing variable has not been used in this study and it could provide more effective knowledge and understanding. A fifth, this study has not studied gender diversification and thus future researches are recommended to examine this aspect as well. The data has been gathered from senior managers and in the future, the studies can try to gather data from a more general perspective that could also help in mitigating any presence of biases. 


\section{References}

Akcigit, U., \& Kerr, W. R. (2018). Growth through heterogeneous innovations. Journal of Political Economy, 126(4), 1374-1443.

Ali, D., Leifu, G., \& Rehman, R.-u. (2016). The impact of technology orientation and customer orientation on firm performance: Evidence form chinese firms. International Journal of Management and Marketing Research, 9(1), 1-11.

Anzola-Román, P., Bayona-Sáez, C., \& García-Marco, T. (2018). Organizational innovation, internal r\&d and externally sourced innovation practices: Effects on technological innovation outcomes. Journal of business research, 91, 233-247.

Azar, G., \& Ciabuschi, F. (2017). Organizational innovation, technological innovation, and export performance: The effects of innovation radicalness and extensiveness. International Business Review, 26(2), 324-336.

Ballot, G., Fakhfakh, F., Galia, F., \& Salter, A. (2015). The fateful triangle: Complementarities in performance between product, process and organizational innovation in france and the uk. Research Policy, 44(1), 217-232.

Bamgbade, J., Nawi, M., Kamaruddeen, A., Adeleke, A., \& Salimon, M. G. (2019). Building sustainability in the construction industry through firm capabilities, technology and business innovativeness: Empirical evidence from malaysia. International Journal of Construction Management, 1-16.

Battisti, G., \& Stoneman, P. (2010). How innovative are uk firms? Evidence from the fourth uk community innovation survey on synergies between technological and organizational innovations. British Journal of Management, 21(1), 187-206.

Bin Zainuddin, Y. (2017). Moderating effect of environmental turbulence on firm's technological innovation capabilities (tic) and business performance in the automotive industry in malaysia: A conceptual framework. Paper presented at the MATEC web of Conferences.

Burgelman, R. A., Maidique, M. A., \& Wheelwright, S. C. (1996). Strategic management of technology and innovation (Vol. 2): Irwin Chicago.

Camisón, C., \& Villar-López, A. (2014). Organizational innovation as an enabler of technological innovation capabilities and firm performance. Journal of business research, 67(1), 2891-2902.

Carboni, O. A., \& Russu, P. (2018). Complementarity in product, process, and organizational innovation decisions: Evidence from european firms. RED Management, 48(2), 210-222.

Chandy, R. K., Prabhu, J. C., \& Antia, K. D. (2003). What will the future bring? Dominance, technology expectations, and radical innovation. Journal of Marketing, 67(3), 1-18.

Chen, Q., Wang, C.-H., \& Huang, S.-Z. (2020). Effects of organizational innovation and technological innovation capabilities on firm performance: Evidence from firms in china's pearl river delta. Asia Pacific Business Review, 26(1), 72-96.

Creswell, J. W. (2002). Educational research: Planning, conducting, and evaluating quantitative: Prentice Hall Upper Saddle River, NJ.

Damanpour, F., Szabat, K. A., \& Evan, W. M. (1989). The relationship between types of innovation and organizational performance. Journal of Management studies, 26(6), 587-602.

Etikan, I., Musa, S. A., \& Alkassim, R. S. (2016). Comparison of convenience sampling and purposive sampling. American journal of theoretical and applied statistics, 5(1), 1-4.

Evangelista, R., \& Vezzani, A. (2010). The economic impact of technological and organizational innovations. A firm-level analysis. Research Policy, 39(10), 1253-1263.

Fornell, C., \& Larcker, D. F. (1981). Structural equation models with unobservable variables and measurement error: Algebra and statistics. Journal of marketing research, 18(3), 382-388.

Gatignon, H., \& Xuereb, J.-M. (1997). Strategic orientation of the firm and new product performance. Journal of marketing research, 34(1), 77-90.

Gemünden, H. G., Lehner, P., \& Kock, A. (2018). The project-oriented organization and its contribution to innovation. International Journal of Project Management, 36(1), 147-160.

Guan, J. C., Yam, R. C., Mok, C. K., \& Ma, N. (2006). A study of the relationship between competitiveness and technological innovation capability based on dea models. European journal of operational research, 170(3), 971-986.

Guimaraes, T., \& Paranjape, K. (2017). The effect of organization innovativeness on company innovation success. International Journal of the Academic Business World, 11(2), 79-92.

Hailekiros, G. S., \& Renyong, H. (2016). The effect of organizational learning capability on firm performance: Mediated by technological innovation capability. European Journal of Business Management, 8(30), 87-95.

Hair, J. F., Ringle, C. M., \& Sarstedt, M. (2011). Pls-sem: Indeed a silver bullet. Journal of Marketing theory and Practice, 19(2), 139-152.

Hair, J. F., Ringle, C. M., \& Sarstedt, M. (2013). Partial least squares structural equation modeling: Rigorous applications, better results and higher acceptance. Long Range Planning, 46(1-2), 1-12. 
Hair, J. F., Sarstedt, M., Ringle, C. M., \& Mena, J. A. (2012). An assessment of the use of partial least squares structural equation modeling in marketing research. Journal of the academy of marketing science, 40(3), 414-433.

Henseler, J., \& Fassott, G. (2010). Testing moderating effects in pls path models: An illustration of available procedures. In Handbook of partial least squares (pp. 713-735): Springer.

Hortinha, P., Lages, C., \& Lages, L. F. (2011). The trade-off between customer and technology orientations: Impact on innovation capabilities and export performance. Journal of International Marketing, 19(3), 36-58.

Ince, H., Imamoglu, S. Z., \& Turkcan, H. (2016). The effect of technological innovation capabilities and absorptive capacity on firm innovativeness: A conceptual framework. Procedia-Social and Behavioral Sciences, 235, 764-770.

Jantunen, A., Ellonen, H.-K., \& Johansson, A. (2012). Beyond appearances-do dynamic capabilities of innovative firms actually differ? European Management Journal, 30(2), 141-155.

Kahn, K. B. (2018). Understanding innovation. Business Horizons, 61(3), 453-46o.

Khan, B. A., \& Naeem, H. (2018). The impact of strategic quality orientation on innovation capabilities and sustainable business growth. International Journal of Quality E Reliability Management.

Kireyeva, a. A., turdalina, s., mussabalina, d., turlybekova, n. M., \& akhmetova, z. B. (2020). analysis of the efficiency technology transfer offices in management: the case of spain and kazakhstan. the journal of asian finance, economics and business, 7 (8), 735-746. https://doi.org/10.13106/jafeb.2020.vol7.no8.735

Kogan, L., Papanikolaou, D., Seru, A., \& Stoffman, N. (2017). Technological innovation, resource allocation, and growth. The Quarterly Journal of Economics, $132(2), 665-712$.

Lee, R., Lee, J.-H., \& Garrett, T. C. (2019). Synergy effects of innovation on firm performance. Journal of business research, 99, 507-515.

Lynham, S. A. (2002). Quantitative research and theory building: Dubin's method. Advances in developing human resources, 4(3), 242-276.

Nguyen, t. l. h., pham, n. t., dao, v. p. l., ngo, t. t. t., \& le, t. t. b. (2020). critical factors affecting the innovation activities of businesses: evidence from binh dinh province, vietnam. the journal of asian finance, economics and business, 7(7), 425-438. https://doi.org/10.13106/jafeb.2020.vol7.no7.425

Rahim, F. B. T., \& Zainuddin, Y. B. (2019). The impact of technological innovation capabilities on competitive advantage and firm performance in the automotive industry in malaysia. Paper presented at the AIP Conference Proceedings.

Sapprasert, K., \& Clausen, T. H. (2012). Organizational innovation and its effects. Industrial and Corporate Change, 21(5), 1283-1305.

Saunders, M., Lewis, P., \& Thornhill, A. (2009). Research methods for business students: Pearson education.

Scandura, T. A., \& Williams, E. A. (200o). Research methodology in management: Current practices, trends, and implications for future research. Academy of Management journal, 43(6), 1248-1264.

Sekaran, U., \& Bougie, R. (2010). Research for business-a skill building approach. In: John-Wiley and Sons, New York, NY.

Sekaran, U., \& Bougie, R. (2016). Research methods for managers: A skill-building approach (7th ed.). New Jersey, USA: John Wiley \& Sons, Inc.

Seyfang, G., \& Smith, A. (2007). Grassroots innovations for sustainable development: Towards a new research and policy agenda. Environmental politics, 16(4), 584-603.

Shafia, M. A., Shavvalpour, S., Hosseini, M., \& Hosseini, R. (2016). Mediating effect of technological innovation capabilities between dynamic capabilities and competitiveness of research and technology organisations. Technology Analysis E Strategic Management, 28(7), 811-826.

Tuan, N., Nhan, N., Giang, P., \& Ngoc, N. (2016). The effects of innovation on firm performance of supporting industries in hanoi, vietnam. Journal of Industrial Engineering and Management, 9(2), 413-431.

Tahar, A., Riyadh, H. A., Sofyani, H., \& Purnomo, W. E. (2020). perceived ease of use, perceived usefulness, perceived security and intention to use e-filing: the role of technology readiness *. the journal of asian finance, economics and business 7(9), 537-547. https://doi.org/10.13106/jafeb.2020.vol7.no9.537

Wang, C.-h., Lu, I.-y., \& Chen, C.-b. (2008). Evaluating firm technological innovation capability under uncertainty. Technovation, 28(6), 349-363.

Welman, C., Kruger, F., \& Mitchell, B. (2005). Research methodology: Oxford University Press Cape Town.

Wong, J. K. W., \& Zhou, J. (2015). Enhancing environmental sustainability over building life cycles through green bim: A review. Automation in Construction, 57, 156-165.

Yam, R. C., Lo, W., Tang, E. P., \& Lau, A. K. (2011). Analysis of sources of innovation, technological innovation capabilities, and performance: An empirical study of hong kong manufacturing industries. Research Policy, 40(3), 391-402. 